\title{
ANALYTICAL HIERARCHY PROCESS (AHP) APPROACH ON CONSUMER PREFERENCES OF RESEDENTIAL HOUSING IN GATED COMMUNITY MANADO
}

\author{
By: \\ Shinta Jeanette Camelia Wangke \\ Faculty of Economy and Business \\ University of Sam Ratulangi Manado \\ Email: snta@snta.us
}

\begin{abstract}
Research Backgroud
Construction growth for the residential property in gated community Manado had reached its highest growth of 7,68\% in Q2 2014. Increasing purchase intention of the house buyers resulted huge increase in the residential housing price in gated community. Since the gated community started to become a trend as a preferred choice for people to stay in, therefore, this study seeks to discover the reason for people to purchase residential properties.
\end{abstract}

\section{Reasearch Objectives}

This research highlighted several criteria that would encourage people to consider when buying a residential house in gated community. The objectives of this research are to analyze consumer preferences criteria on residential housing in gated community, identifying which criteria has influence the most and which residential housing people want the most based on the residential housing in gated community alternatives

\section{THEORITICAL FRAMEWORK}

\section{Consumer Preferences}

Consumer preferences are defined as the subjective (individual) tastes, as measured by utility, of various bundles of goods. They permit the consumer to rank these bundles of goods according to the levels of utility they give the consumer. Preferences are independent of income and prices. Ability to purchase goods does not determine a consumer's likes or dislikes. A consumer preference explains how a consumer ranks a collection of goods or services or prefers one collection over another. This definition assumes that consumers rank goods or services by the amount of satisfaction, or utility, afforded. Consumer preference theory does not take the consumer's income, good or service's price, or the consumer's ability to purchase the product or service (www.ehow.com/definition-consumerpreference.html).

\section{Gated Community}

Blakely and Snyder (1997) defined Gated community as a residential areas that have restricted and limited entrance where by these areas had being privatized. Normally, restricted obstacles such as fences or walls were built to prevent the entrance by non-residents without legal permission. According to Vroom (1964), individuals behavior depends on the types of outcome expected and they get motivated by behave accordingly, based on their favorable combination of expectation and level of 
importance. Different in market segmentation considered different reasons when make a purchase decision of a residential property in gated community (Schafer, 2009). Garland (2001) indicated that the main reasons for the growth of the gated community in United Kingdom are concern on criminal offences, anti-social behavior and vandalism. Hope (1998) found that community safety has become the most concern of every individual. However, Shearing (1995) and Davis (1990) found that the increase in gated community in many countries was signs of segregation according to social class among the rich and the poor.

\section{Property Market Outlook}

Based on Bank Indonesia Report for 2014, Indonesia's residential property price index (14 major cities) rose by $7.88 \%$ during the year to end-Q2 2014, but this is a significant slowdown on $12.11 \%$ year-on-year price increases during the same period last year (all figures from Bank Indonesia). Residential property has been attractive to rich Indonesians and others partly as a protection against inflation. All Indonesia's major cities saw nominal property price rises. Makassar led the market with house price increases of $19.28 \%$ (11.89\% inflation-adjusted) during the year to Q2 2014. It was followed by Manado (13.36\% nominal).

\section{Consumer Preferences Criteria on Residential Housing in Gated Community}

Adair et.al (1996) have done a series of analysis on the British and American evaluation based on econometric literature and derived 55 variables and classified these variables into 4 categories such as property, distance, environmental and financial are the four characteristics that buyers have purchase intention on property

\section{Financial}

Prices of residential house are much higher as compared to houses in open space, people tend to purchase such houses may depends on the level of disposable income (Bible\&Hsieh ,2001; Blandy\&Parsons, 2002; LaCour-Little\&Malpezzi, 2001). High level of disposable income in a country increases the spending power of a nation. Owning a house is a major goal of a person. Frank (2007) had reveals in his survey that long-term investment is also a key factor for the UK home owners in choosing their current primary residents. In short, acquisition of a house is not only motivated by consumption purpose, but also as an investment purpose.

\section{Distance}

Study from Daly et al. (2003) had shown that location is an important aspect for buyers to consider when purchase a property. Perceived on location between distance with their interest constitute purchase intention to the property. For example, residential houses in gated community that is proximity to city, work places, school, amenities and central business district. Distance to the places of interest among prospective or existing house buyers constitute a significant reason for them to live in gated community. Households are willing to buy different kind of rights to fulfill their personal requirement (Webster \& Wu 2001; Webster\& Lai 2003).

\section{Property Physical}

Abelson and Chung (2005) pointed out that purchase preferences of buyers are highly correlate with the quality of property. The research on housing prices which carried out in Australia between 1970 and 
2003 had shown that quality of houses tends to increase over the years. It was because the raising in the standard of living increases the customer expectation on the physical design of a house, especially those in gated community. The typical perception of gated community is that technological innovation and design increase segregation and privatism of the community in a country. According to Abelson and Chung (2005), amount of management fees imposed, décor of houses, size of houses, building of "green housing" were the consideration for house buyers to consider when make purchase on the relative houses. Ling (2006) found that there is a relationship on the space area of houses towards the preferences of residential housing in gated community. Gated community with large open space allotment can foster the cohesion of neighborhood regardless the location of the gated residential houses

\section{Environment}

Forrest and Kearns (2001) had done investigation on the level of importance between the neighborhood and neighboring and they found that a sense of neighborhood and the good environment in the surroundings that was wall established are crucial in promoting positive personal development of a community, although it is hard to measure how strong of the relationship between the gated community and physical structures of environment. According to Ling (2006), physical design of environment structures in gated community tends to bring long-term benefits to the residents, even for the future generation who stay in gated community. According to Rossi (1980), neighborhood safety is highly related to the neighborhood environment. Improving in quality of neighborhood environment will increase the concern of residents in gated community over the appearance of the neighborhood and the kind of people who live in their community. This could enhance their perceived level of neighborhood safety and produced positive effects on social integration within the community. (Baba\&Austin, 1989)

\section{Conceptual Framework}

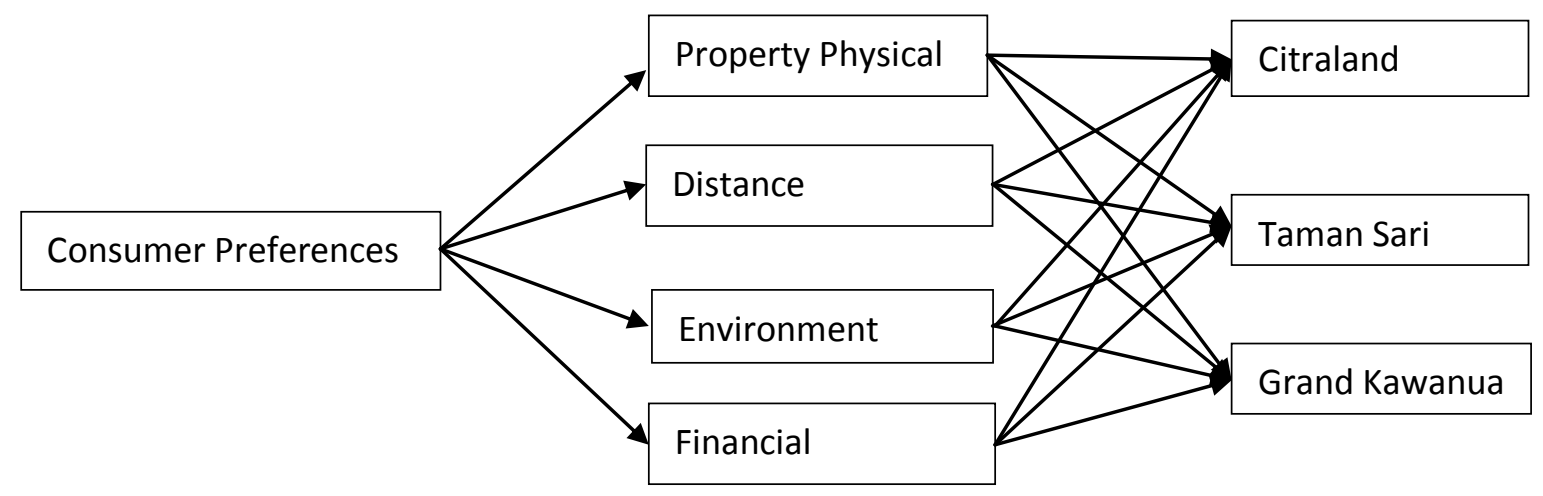

Figure 1. Conceptual Framework

\section{RESEARCH METHOD}

\section{Type of Research}

This research is quantitative research. Type of research is an exploratory research to analyze consumer preferences criteria on residential housing in gated community Manado. 


\section{Place and Time of Reseach}

The research was conducted in Manado particularly at residential housing in gated community of Citraland, Tamansari and Grand Kawanua. This research use their customers as the respondents, and held on May-June 2014.

\section{Population and Sample}

Sekaran and Bouggie (2010) defined population is the entire group of people, events, of things of interest that the researcher wishes to investigate. The population that is mainly observed in this current research is prospective consumers from three alternatives (Citraland, Tamansari, Grandd Kawanua). The sampling design is Purposive sampling to 50 respondents that is the way researcher do the observation and the way of getting the information in effective and efficient way.

\section{Data Collection}

This research the source of data consists of primary and secondary data. Primary data has been obtained by spreading questioners to the respondents and the secondary data has been collected from books and all relevant articles from the library and Internet.

Operational Definition and Measurement of Research Variables

This research defines the variables into:

1. Consumer Preferences ( $Y$ ) defined as the subjective (individual) tastes, as measured by utility, of various bundles of goods a process of gathering and processing information, evaluating it and selecting the best possible option to make a buying choice or to make decisions regarding product and service offerings.

2. Preferences Criteria (X) means factors that influencing people or reason why people want to purchase a residential housing in gated community.

3. Alternatives: Citraland (1), Tamansari (2), Grandd Kawanua (3)

\section{Data Analysis Method}

\section{Analytic Hierarchy Process}

The Analytic Hierarchy Process (AHP) is a mathematical technique for multi-criteria decision making. Saaty (2008). It enables people to make decisions involving many kinds of concerns including planning, setting priorities, selecting the best among a number of alternatives, and allocating resources. The Analytic Hierarchy Process (AHP) is a powerful and flexible decision making process to help people set priorities and make the best decision when both qualitative and quantitative aspects of a decision need to be considered. By reducing complex decisions to a series of one-on-one comparisons, then synthesizing the results, AHP not only helps decision makers arrive at the best decision, but also provides a clear rationale that it is the best.

We conduct AHP in three steps:

1. Perform pairwise comparisons

2. Compute the relative weights

3. Assess consistency of pairwise judgments 


\section{Operational Definition and Measurement of Research}

Table 1 Pair Wise Scale

\begin{tabular}{|l|c|}
\hline \multicolumn{1}{|c|}{ Preference Level } & Numerical Value \\
\hline Equally Preferred & 1 \\
\hline Equally to moderately preferred & 2 \\
\hline Moderately Preferred & 3 \\
\hline Moderately to strongly preferred & 4 \\
\hline Very strongly preffered & 5 \\
\hline Very Strongly to extremely preffered & 6 \\
\hline Extremly Preferred & 7 \\
\hline
\end{tabular}

Source: Processed Data, 2014

1. Synthesization The next step in AHP is to prioritize the decision alternatives within each criterion. Steps in synthesization are:

a) Sum the values in each column of the pairwise comparison matrices.

b) Divide each value in each column of the pairwise comparison matrices by the corresponding column sum-these are normalized matrices.

c) Average the values in each row of the normalized matrices-these are the preference vectors

d) Combine the vectors of preference for each criterion into one preference matrix that show the preference for each criterion

2. Develop a pairwise comparison matrix for the criteria.

3. Compute the normalized matrix by dividing each value in each column of the matrix by the corresponding column sum.

4. Develop the preference vector by computing the row averages for the normalized matrix.

5. Compute an overall score for each decision alternative by multiplying the criteria preference vector by the criteria matrix.

6. Rank the decision alternatives, based on the magnitude of their scores computed in step 6.

\section{RESULT AND DISCUSSION}

\section{Result}

Result of the overall criteria of consumer preferences on residential housing in gated community

\begin{tabular}{|l|l|l|l|}
\hline Property Physical & Environment & Distance & Financial \\
\hline 0.1993 & 0.6535 & 0.0860 & 0.0612 \\
\hline
\end{tabular}

In this result shows the highest priority criterion is Environment (0.6535). It's measured as the factor that have influence most people in selecting residential housing. The second is Property Physical as many as (0.1993), followed by distance (0.0860) and financial as the lowest score (0.0612).

\section{Result of Analytical Hierarchy Process on consumer preferences in selecting residential housing}

\begin{tabular}{|l|l|l|}
\hline Citraland & Tamansari & Grand Kawanua \\
\hline 0.3091 & 0.1595 & 0.5314 \\
\hline
\end{tabular}


Consumer preferences in selecting residential housing in terms of alternatives that been given, they prefer to choose Grand Kawanua as the most preferred residential housing among the other alternatives. Grand Kawanua being the highest score as many as (0.5314), and in the second highest position is by Citraland with total score (0.3091), and followed Taman Sari in the last position with total score (0.1595).

Result of Analytical Hierarchy Process Cosistency

\begin{tabular}{|l|l|}
\hline & Degree of Consistency \\
\hline Overall Criterion & 0.0580 \\
\hline Property Physical & 0.0826 \\
\hline Environment & 0.0703 \\
\hline Distance & 0.0942 \\
\hline Financial & 0.0826 \\
\hline
\end{tabular}

In this case the degree of consistency is satisfactory, there are consistencies and the AHP results is valid.

\section{Discussion}

Pairwise Comparison for the Main Criteria Analysis

In Analytical Hierarchy Process (AHP), the criterion developed as the measurement of alternatives residential housing has been compared. AHP determines the relative importance or weight of the criteria, to rank the criteria from most important to least important. A criterion with the highest average weight indicates the priority criteria among others.

Overall, based on the result all the respondents indicate that all these criterion were considered important for decision making in selecting residential housing in gated community. It can be seen clearly in the result of overall criterion on consumer preferences. Based on the result people tend to prefer environment the most. Environment is measured by condition of neighborhood, attractiveness of the area, security available over the crime and last but not least security from disaster (flood, landslide, etc). It than shows the level of importance between the neighborhood and neighboring and also found that a sense of neighbourhood and the good environment in the surroundings that was well established are crucial in promoting positive personal development of a community.

Second Place is property physical. The raising in the standard of living increases the customer expectation on the physical design of a house, especially those in gated community. The typical perception of gated cLommunity is that technological innovation and design increase segregation and privatism of the community in a country. The quality of property physical measured by size, design, type and how well the house build. By being second it shows that the quality is also an important factor that could helping people to cope with an unattractive physical environment

The third criteria that consumer prefer is distance. Location is measured by the proximity to city, work, shopping centre and central business district. In this context, distance factor itself had a variety of meaning to the house buyers. To note that this research is held in manado area where the distance from 
one destination to another not that far away, also that the respondents comes from close residential housing. Based on the finding result, good location can improve user preferences on selecting residential house regardless the financial factor.

The last criteria is Financial that measured by value of the house and the choices of payment system. Prices of residential house are much higher as compared to houses in open space, people tend to purchase such houses may depends on the level of disposable income. Since the respondents are from the residential housing for middle and upper class, they tend to purchased a house motivated not only by consumption purpose, but also as an investment purpose. That may be the reason why the intend to prefer environment, property physical and distance over financial. By being last doesn't mean that financial is not considered when selecting residential housing. It just means that it is least prefer compare to the other three criteria

Result of Analytical Hierarchy Process of consumer preferences in selecting residential housing.

The overall result of consumer preferences in selecting residential housing in gated community shows that they will choose Grand Kawanua among the other alternatives based on the criteria that have been considered. Followed by Citraland and Taman Sari at the last.

\section{CONCLUSION AND RECOMMENDATION}

\section{Conclusion}

The result of this research shows the conclusion stated below, which are:

1. People tend to select gated house because of the environment. Environment have influence and affect consumer preferences the most when selecting residential housing in gated community particularly in Manado. Analytical Hierarchy Process (AHP) shows the first and the highest total score goes to environment. Environment being the most preferred by respondents based on the data comparison developed in pairwise comparison of analytical hierarchy process (AHP). The second position of the highest scored is placed by property physical, and followed by Distance and Financial criteria.

2. The overall result in Analytical Hierarchy Process, the finding shows Grand Kawanua become the most preferred Residential Housing in gated community in terms of criteria choosing by the customers followed by Citraland and Grand Kawanua.

\section{Recommendation}

There are three-recommendation base on the conclusion above, which are:

1. Environment plays important roles in consumer preferences in the needs of selecting a residential housing in gated community. Environment becomes a priority consideration by the respondents that influence and affect the most. Therefore, every housing developers particularly in Manado has to pay attention seriously toward this factor. For customers, they absolutely would not select a residential housing that not promoting positive personal development of a community. Moreover, for housing developer, security availability against crime or disaster is crucial part to keeping customer loyalty. Regarding above, housing developer need to improve and keep their overall performance related to 
consumer preferences criteria, in order to more consider how to build and protect their competitive position in the market. As for the government, a good housing development project should constantly be revised to satisfy the need of house buyers by providing a safe and secure neighborhood.

2. Grand Kawanua's competitors in housing residential in gated community such as Citraland and Taman sari have to improve their performance and should more focus in terms of consumer preferences criteria since Grand Kawanua dominates the best performance in almost all priority criteria that make this firm able to attract more consumers.

\section{REFERENCES}

Abelson, P.W. \& Chung, D. 2005, "Housing Prices in Australia: 1970 to 2003". Macquarie University,Sydney.

Adair, A., Berry, J. \& McGreal, S. 1996. "Valuation of Residential Property: Analysis of ParticipantBehaviour", Journal of Property Valuation \&Investment, vol.14, no.1, pp.20-35.

Bank Indonesia. 2014, Kajian Ekonomi Regional Provinsi Sulawesi Utara Triwulan II Tahun 2014.

Bible,D.S.\& Hsieh,C.H. 2001, "Gated communities \& residential property values" The Appraisal Journal, Louise Lee Lum Library, United States.

Blakely,E. \& Snyder, M. 1997, Fortress America, The Brookings Institutions, Washington.

Blandy,S. \& Lister,D. 2002, Gated Communities: A Systematic Review of the Research Evidence," Sheffield Hallam University, United Kingdom.

Daly,J.Gronow,S.Jenkins,D. Plimmer,F. 2003, "Consumer behaviour in the valuation of residential property:A comparative study in the UK, Ireland and Australia", Property Management, vol21, no.5, pp.295-314.

Frank. 2007, 07 Annual Wealth Report: Prime Residential Property, Knight Frank LLP,London, pp.1-30

Hope, T. 1998, Community Safety, Crime \& Disorder in Marlow ,A\&Pitts,J.(eds). 1998, Planning Safer Communities, Russell House ,Dorset

Saaty, 2008. T.L. Saaty Decision making with the analytical hierarchy process International Journal of Services Sciences., 1 (1) (2008), pp. 83-98

Schafer,D. 2008, "Revolution or renaissance: making the transition from an economic age to a cultural age", University of Ottawa Press, Ottawa

Uma Sekaran \& Bougie, R. (2010). Research Methods for. Business: A Skill Building Approach. UK: John Wiley \& Sons 
Vroom,V.H. 1964,"Work \& Motivations, Wiley Publication, New York. Ireland and Australia", Property Management, vol.21, no.5, pp.295-314

Webster,C. \& Wu, F. 2001, "Coase, spatial pricing and self - organising cities", Urban Studies, vol.38, pp. 2037-2045.

www.ehow.com/definition-consumer-preference.htm 